\title{
DOCUMENTÁRIO
}

\section{UMA INSURREIÇÃO DE ESCRAVOS EM CAMPINAS.}

\section{SUELY ROBLES REIS DE QUEIROZ}

do Departamento de História da Faculdade de Filosofia, Letras e Ciências Humanas da Universidade de São Paulo.

Até há algum tempo atrás prevaleceu na historiografia sobre a escravidão brasileira a idéia de uma instituição benévola, se comparada à de áreas alienígenas. Como corolário dessa idéia subsistia a de um negro escravo passivo por natureza, submetido pacificamente à condição de que era vítima .

Embora sofrendo contestação de alguns estudiosos (1) somente em período mais recente tem-se observado na historiografia uma preocupação com a revisão de tais noções (2) .

Nesse sentido vai emergindo a idéia de que, à violência do sistema escravista teria correspondido uma ação igualmente violenta do ne-

(1). - Artur Ramos adverte que há na história da escravidão brasileira "muita coisa a assinalar que revela o protesto às vezes violento que o negro ergueu contra a sua condição de escravo" - ("Castigos de escravos" in aculturação negra no Brasil, São Paulo, 1942, p. 55). E João Ribeiro lembra que "rão tão raras quanto podem parecer, havia por todo o tempo da escravidão as sublevações dos negros" (História do Brasil - para o Curso Superior - Rio de Janeiro, 1957, p. 385) .

(2) . - A historiografia recente tem procurado mostrar a violência do sistema escravista. (Ver, entre outros, Fernando Henrique Cardoso, Capitalismo e escravidão no Brasil meridional, São Paulo, 1962; Emília Viotti da Costa, Da senzala à colônia, São Paulo, 1966).

Tambem José Honório Rodrigues em "As tendências da historiografia brasileira e as necessidades da pesquisa", (Vida e História, Rio de Janeiro, 1966) combate a idéia de brandura em relação ao escravismo brasileiro.

Em $1964 \mathrm{um}$ autor norte-americano (Stanley Stein, "A historiografia do Brasil 1808-1889", Revista de História $\mathrm{n}^{\circ}$ 59, p. 109 e segs.) mostrava a necessidade de estudos visando a essa revisão e mais recertemente um outro autor, tambem norte-americano, notaria os esforços realizados nesse sentido (Richard Graham, "Brazilian Slavery re-examined: a review article", from Journal of Social History, vol. III, no 4, 1970. University of Texas at Austin, Institute of Latin American Studies). 
gro escravo, tão frequente e concreta quanto the permitissem os acanhados meios de que dispunha (3).

Em relação a São Paulo, a documentação existente no Arquivo do Estado dá margem à negação da passividade do escravo, apontando-lhe o inconformismo ante a falta de liberdade e os maus tratos a que era submetido.

A instituição escravista ali só seria significativa no século XIX, quando, através da lavoura de cana, a região se integra em uma economia de exportação, obedecendo ao trinômio tradicional: latifúndio, monocultura, escravidão negra .

Aí então o sistema acompanharia as características gerais vigentes nas demais regiões de grande lavoura do país-coerção, repressão e consequente violência constituiriam as formas de controle utilizadas pela sociedade para assegurar a manutenção do trabalho escravo.

Submetido a um sistema violento, reagiria o cativo de forma tambem violenta, renegando o regime e a falta de liberdade que dele decorria, através de mecanismos de resposta os mais variados.

Um desses mecanismos de resposta foi o da insurreição, definida pelo Código Criminal como reunião de

"vinte ou mais escravos para haverem a liberdade por meio da força".

Frequente em São Paulo durante todo o perío do escravista, a do documento que ora transcrevemos ocorreu em Campinas (4) em 1832 E incluía escravos de quatorze fazendas da região. No manuscrito em questão; até aqui inédito (5), encontram-se os depoimentos dos cati-

(3). - Em Rebelióes da Senzala, a primeira tentativa sistemática de estudo da massa escrava e de alguns dos seus movimentos de rebeldia, Clóvis Moura procura mostrar que esses movimentos não foram esporádicos e constituiram uma sequência decorrente da própria estrutura econômico-social da Colônia e do Império.

(4). - Campinas deteve avultado número de escravos durante todo o período do escravismo negro em São Paulo e como tal, esteve sujeita a constantes sublevações. Zona produtora de açuícar a princípio, transformou-se em região cafeeira a partir da metade do século aproximadamene, exigindo sempre e sempre o concurso do braço negro.

(5). - Há referências sobre essa insurreição em diversos autores, alguns dos quais trarscreveram documentos relativos à mesma como é o caso de Júlio Mariano em Campinas de ontem e anteontem, São Paulo, 1970. O manuscrito todavia que ora apresentamos e que encerra uma verdadeira devassa permanecia inédito. 
vos implicados na trama, através dos quais, chega-se a constatações interessantes: a da existência no movimento de objetivos definidos, e qualidades de organização e liderança que não se compadecem com a "coisificação" do escravo imposta pelo sistema.

Não passou de tentativa, pois, suspeitando do fato, alguns fazendeiros representaram às autoridades que imediatamente aplicaram

"os meios menos estrepitosos e menos prejudiciais e todavia os mais enérgicos para sufocar tal ou a reprodução de semelhante tentativa no presente" (6).

Juizo de Paz da Villa de Sam Carlos.

Carta Precatoria de deligencia do Juizo de Paz desta Villa derigida aos da Imperial Cidade de São Paulo, afim de ser capturado o Reo João Barbeiro d'Nasção, como abaixo se declara ex officio (7).

A Vossa Senhorias Meretissimos Senhores Juizes de Paz da Imperial Cidade de São Paulo, atodos em geral, e cada hum depersi em particular, em seus respectivos Destrictos, Freguezias, e Lugares. Eu José da Cunha Pais Lemes Juis de Paz desta villa de Sam Carlos, comarca da Fidelissima Villa de Itu.

Faço saber que neste meu Juizo, eperante mim, me foi dada huma denumcia de insurreição premeditada pelos escravos de alguns Engenhos pertencentes ao meu Destricto, em concequencia a aceitei, procendo, mandei autuar, epara poder proceguir nos termos com individuação, nomeei Promotor, Curador e Inquiridor, para figurarem: aquelle Promotor, como Accuzante Autor, e este como curador, e Inquiridor por parte dos Escravos, esatisfeito es preceito, se continuou na Inqueriçam, e ferida ella quanto necessario foi para conhecimento de cauza procedi na Sentença com assistencia de Assessor, que tudo verbo ad verbum he do teor, forma e maneira seguinte $=$ Mil oito centos trinta e dous $=$ Juizo de Paz da villa de São Carlos.

Folha, huma $=$ Autos crimes de procedimento ex officio sobre o Projecto de inssurreição dos Escravos deste Termo = Joaquim Soares de Carvalho Promotor $=$ João Maria de Couto,

(6). - Mss. do Arquivo do Estado de Säo Paulo, ofício de 27 de fevereiro de 1832 , Ofícios diversos de Campinas, cx. 56.

(7). - Mss. do A.E. S. P., Ofícios diversos de Campinas, cx. 56, pasta 2 , documento 80 . 
Curador $=$ Escrivam Monteiro $=$ Ano do Nascimento de Nosso Senhor Jesus Christo demil oito centos trinta e dous undecimo da Independencia e do Imperio; aos trez dias do mes de Fevereiro do dito anno, nesta villa de São Carlos, Comarca de Itú, Provincia de São Paulo, em casas do Juis de Paz Jose da Cunha Paes Leme, aonde eu Escrivam de seu cargo aodiante nomeado fui vindo esendo ahi pelo dito Juiz me foi apprezentado hum officio do Sargento Mor Antonio Francisco de Andrade em data de trez de Fevereiro do corrente anno, e outro em data de sete do dito mez e anno em os quais denunciava a este Juizo a attentativa de insurreição, que projctavão os escravos de alguns Engenhos do Termo desta dita villa, e sendo semelhante objecto da mais alta consideração, mandu elle Juiz, que se autuasse adita Denuncia; e logo nomeou por Portaria de trez do dito mez e anno, a Joaquim Jose Soares de Carvalho para Promitor; e João Maria de Couto para Curador, e Inquiridor; aos quaes se officiou; e em consequencia do que se aprezentaram neste Juizo, eprestarão o devido juramento.

Elogo o dito Promotor fez Petição ao dito Juiz para se proceder a Auto de corpo de delito indirecto, epara se seguirem os termos do Processo sem confuzão a seu Despacho digo confuzã̀o o que assim foi deferido pelo dito uis em seu Despacho: bem como fez omesmo Promotor outra Petição para os inquiritorios dos Livres serem separados dos interrogatorios dos pretos, o que dado ao diante se segue.

Do que para constar fiz esta autuação. Eu Manoel Francisco Monteiro Escrivam de Paz a escrevi.

\section{DENUNCIA .}

Participo avossa Senhoria que entrando eu e varios prprietarios da beira do Rio d'Ativaia, meus vizinhos na desconfiança de que nossos escravos projectavão algum trama contra nós, em razão de descubrirmos, que ellès nocturna, e escandalezamente se comunicavão huns com os outros aonde depois de comerem e beberem juntos para poderem iludir a aquelles dos quaes os capitaens não confiavam oplano, alguns delles se apartavam, e hião para diversas partes conferinciar com outros de confiança: sabendo nos tudo isto, e depois de hum ajuntamente nocturno que elles fizerão no Engenho de Donna Anna Franca na noite do dia sabbado, vinte eioto do mez de Janeiro proximo passado, 
assentamos nós de comum acordo de n'um mesmo dia chamar mos alguns ds nossos escravos, aquelles que nos parecião mais habeis, e capazes de alguma empreza e obriga-los a que por via de promessas a hums, e de castigos a outros nos declarassem a que se destinavão as suas viagens nocturnas, e quaes erão os fins de semelhantes ajuntamentos.

Postos pois em perguntas no mesmo dia e seguintes em trez engenhos, e depois de algum castigo confessarão alguns dos meus escravos, e outros de Theodoro Francisco de Andrade:

$1^{\circ}$ - Que para ficarem libertos se comunicavão com o preto João Barbeiro, que então morava nesta villa, e que foi prezo e remettido para a cidade de São Paulo por ser cabeça do Levante, que não se fez pela Pascoa, e que o tal negro João era forro.

$2^{9}$ - Que as ordens do dito João Barbareiro são trazidas da Cidade por hum escravo tropeiro de Joaquim Jose dos Santos, chamado Marcelino.

$3^{\circ}$ - Que este as comunica a hum escravo de Teodoro Francisco de Andrade, chamado Miguel, o qual deve ser comandante dos escravos da beira de Atibaia.

$4^{0}-$ Que em cada Engenho há hum negro que he capitam, ao qual todos obedecem.

$5^{\circ}$ - Que já tem algum dinheiro em caixa, para qual concorria cada negro com trez, duas e athe com huma pataca, e que este dinheiro esta na mão de outro escravo de Joaquim Jose dos Santos, chamado Diogo.

$6^{\circ}$ - Que todas, as particjpações de huns para outros Engenhos se fazem de noite em animais dos mesmos Senhores e dos carpiriteiros que se achão trabalhando no Engenho.

$7^{0}$ - Que nem todos os sabedores das participações que vem da Cidade e que os de Nasção Monjolo, e congo são os mais influentes.

$8^{\circ}$ - Que alguns confeção que para o levante projectado para a Pascoa, que elles vierão promptos, com suas zagalhas metidas dentro de porungas mas que o levante não se efetuou por ordem do comandante.

Tenho levado ao conhecimento de Vossa Senhoria a fiel narração do que tenho descoberto, e bem que não tenho dado este negocio por concluido, vista a delicadeza delle, com tudo acho 
do meu dever cominicalo, quanto antes a Vossa Senhoria, não só para que Vossa senhoria tome as medias que achar convenientes, como tão bem para levar ao conhecimento do Excellentissimo Senhor Prezidente com a brevidade possivel, visto que o cabeça João Barbeiro existe na capital, e parece que elle deve ter promovido pelas outras villas da Provincia amesma desordem.

Deos guarde a Vossa Senhoria. Villa de São Carlos trez de Fevereiro de mil oito centos trinta e dous.

Illustrissimo Senhor Capitam José da Cunha Paes Lemes Juiz de Paz villa Antonio Francisco de Andrade = Pela Rellação junta verá Vossa Senhoria os Negros que neste Bairro pertendião fazer a revoluçăo, e só não pertencem a este Bairro os da Fazenda Rio das pedras $=$ Tacuaral $=$ Monjolinho, e São Bento, de quais Fazendas devem contar que são os comandantes dos outros Bairros, visto que os meus escravos, e do Alferes Teodoro, dizem cada Bairro tem seu comandante, e que só conhecem aquelles que cujos nomes vão na rellação; por isso Vossa Senhoria, fara as diligencias que the parecer acertadas.

Não remetto os meus por já estarem castigados, porem se for perciso com sua ordem inviarei. Deos guarde avossa Senhoria muitos annos Fazenda sete de Fevereiro de mil oito centos trinta e dous Illustrissimo Senhor capitam Jose da Cunha Paes Leme. Antonio Francisco de Andrade.

\section{RELLAÇÃO.}

Bom Jardim = Francisco tem Espeingarda, estatura baixa $=$ Fazenda das Duas pontes do Capitão Mor Floriano Bento Monjolo, capitam $=$ Benedicto Ferreira $=$ João congo tropeiro $=$ Ponte alta do mesmo senhor $=$ Constantino Monjolo capitam Elias $=$ Antonio $=$ Fabiano crioulo $=$ Fazenda da Senhora Dona Anna de Campos $=$ Joaquim Congo Capitão $=$ Tristão $=$ Americo crioulo $=$ Felizardo $=$ Jacinto Benguella $=$ Malaquias $=$ Fazenda do Rio das Pedras do falescido Francisco Ignacio = Jose Bexiga capitam = Fazenda do Tacuarál, João Monjolo capitam = Fazenda do Monjolinho, Jose duro - capitam - Fazenda de São Bento do capitam Mor Floriano Januario cabiuda capitam $=$ Antonio Cabiuda $=\mathrm{Da}$ mesma Fazenda, Francisco, Francisco Monjolo, e Joze congo $=$ Fazenda de minha May, Miguel Monjou o capitão $=$ Frandigo capitam $=$ Fazenda do Alferes Teodoro Francisco de Andrade Miguel Monjolo comandante 
Fazenda do Senhor Joaquim Jose dos Santos, Diogo caina = Marcelino Monjolo, Tropeiro que trazia as insinuações da Cidade = Fazenda do Capitão Jose da Cunha Paes Leme, João Congo = Manoelzinho $=$ Fazenda de Salvador Bueno Bento cassuada, Joaquim Tropeiro $=$ Fazenda de Antonio Correa Barbosa, Agostinho monjolo, Ignacio $=$ Fazenda sete de Fevereiro de mil oito centos trinta edous, Antonio Francisco de Andrade =

\section{PETIÇAO.}

Illustrissimo Senhor Juiz de Paz. Diz Joaquim Jose Soares d'Carvalho na qualidade de Promotor deste Juizo que a vista das participações, officiais dirigidas a Vossa Senhoria em datas de trez de fevereiro esete do mesmo mez do corrente anno de mil oito centos trinta e dous do Sargento Antonio Francisco de Andrade sobre a insurreição projectadas entre a escravatu:a deste Termo, se deve tomar perante este Juizo sumario conhecimento em forma legal principiando se pelo Auto de corpo de delito, organizando se no modo possivel para se seguir o processo conforme ao Direito estabelecido, e a despozição da novissima carta de Lei de vinteseis de Outubro do anno de mil oito centos centos trinta, e hum, em quanto for applicavel ao caso prezente, por tanto Pede a Vossa Senhoria se sirva mandar proceder ao Auto de Corpo de delito, e que seja o Processo em forma legal, e receberá merce $=$ Despacho Proceda-se a auto de corpo de delito com urgencia .

São Carlos treze de Fevereiro de mil oito centos trinta e dous Cunha $=$ Juizo de Pas da villa de São Carlos.

\section{AUTO CORPO DE DELITO.}

Auto d'Corpo d Delito indirecto. Anno do Nascimento de Nosso Senhor Jezus Christo de mil oito centos, trinta e dous, undécimo da Independência, e do Imperio, aos trez dias do mez de Fevereiro do dito anno nesta villa d' Sam Carlos, em casas do Juis de Paz o capitam Jose caCunha Paes leme onde eu Escrivar de seu cargo ao diante nomeado, fui vindo para o effeito de proceder a Auto de corpo de Delito indirecto na forma, epara o caso declarado na petição retro. Do que para constar fiz esta autuação Eu Manoel Francisco Monteiro Escrivam de Paz o escrevi. 


\section{ASSENTADA .}

Elogo no mesmo dia, mez e anno declarado no auto supra nesta villa de São Carlos em casas do Juiz de Paz Jose da Cunha Paes Leme, onde eu Escrivam ao diante nomeado me achava, por elle Juiz me foi determinado fizesse a prezente assentada, para de baixo della serem inquiridas, e perguntadas, as testemunhas, cujos nomes, naturalidades, idade, qualidades, estados, domicilios, vidas e costumes ao diante vão, seguem.

Do que para constar fis este Termo de Assentada Eu Manoel Francisco Monteiro Escrivam de Faz o escrevi.

\section{DEPOIMENTO DAS TESTEMUNHAS.}

O sargento mor Antonio Francisco de Andrade, homem branco, casado natural desta villa digo nctural da villa de Parnaiba, emorador desta, de idade que disse ter, quarenta eseis annos, que vive de seu Engenho, de assucar, e do costume nada digo e do costume disse ser o proprio denunciante, e hum dos Proprietarios.

Testemunha jurada aos Santos Evangelhos em hum livro delles em que pos sua mão direita sob cargo do qual the foi por elle Juis encarregado dicesse a verdade que soubesse, e perguntado the fosse; e recebido por elle testemunha o dito juramento, assim a presente cumpriu.

E logo disse, que faltando the hum seu escravo de nome Francisco, as suas ordens, o castigou, apezar disto continuou a desobedecer, e entrando no conhecimento de que fazião ajuntamentos nocturnos, a onde se juntavão seus escravos, e os de outras Fazendas vizinhas, e fazião seus clubs, e entrando elle testemunha na indagação de taes ajuntamentos com seu Irmão o Ajudante José Franco de Andrade, e o Alferes Teodoro Francisco de Andrade, de onde por estes, e outros semelhantes motivos, mesmo pela falta da devida obediencia, pegarão em huma parte de escravos do quaes se suspeitava fossem capazes de huma empreza malicioza, principiando a castigar parte delles, bem como os - da Mai delle testemunha, e entre escravos, hum de maior confidencia que sempre foi delle testemunha, sendo chamado por meio de amizade depois de ser castigado, e fazer lhe ver ao dito escravo Jose congo, que elle testemunha sabia de tudo quanto elles manoblavão, mas como aịnda lhe tinha algum resto de amizade, se lhe fizessese ver 
digo se the - fizesse - huma verdadeira confissão, sem que nella the faltasse, couza alguma, ficaria perdoado.

Com estas palavras o escravo dito, assentou que elle testemunha era sabedor de tudo, e principiou a descubrir o que tramavão, e o que está descripto no officio de trez de Fevereiro do corrente anexo, e outro de sete do dito mez, qua acompanhava a rellação, que tudo remettera a este Juizo, e a que tudo se reportava, tendo de mais a apresentar as armas que forão achadas dos mesmos escravos, que vem a ser, huma espada, e huma zagalha, e as mais não apparecerão, suppondo havellas escondido, e mais não disse.

E lido o seu depoimento, pelo achar conforme assignou com elle Juiz. Eu Manoel Francisco Monteiro Escrivam de Paz o escrevi $=$ Cunha $=$ Antonio Francisco de Andrade.

\section{TESTEMUNHA.}

O Ajudante Jose Franco de Andrade homem branco cazado, natural da villa de Parnaiba, emorador desta, da idade de trinta e hum annos, que vive interessado no Engenho de Assucar da sua Mai.

Testemunha jurada aos Santos Evangelhos, em hum livro delles, em que pos sua mão direita, sobcargo do qual prometteu dizer a verdade que soubesse, e perguntado lhe fosse.

Esendo lhe perguntado o que sabia respeito ao contheudo na petição retro do Promotor Joaquim Jose Soares de Carvalho, que toda the foi lida e declarada.

Disse, que sendo prezente as averiguações a que atal respeito procedeo seu Irmão o Sargento Mor Antonio Francisco d'Andrade, se lembra ouvir do escravo Jose congo do dito seu Irmão, que estes ajuntamentos se fazião por insinuações do Escravo Miguel que he do Alferes Teodoro Francisco de Andrade Irmão delle Testemunha, o qual tinha comunicações com hum escravo de Joaquim Jose dos Santos de nome Marcelino, por que este Marcelino tropeiro nas suas hidas a Sam Paulo, trazia insinuações de João Barbeiro actual rezidente na dita cidade de Sam Paulo, reputado cabeça de motim como já o fora no projecto em outro anno p?ssado que he o que forap rezo e remettido esta villa para as cadeas de São Paulo pelo mesmo facto, e que ouviria mais do meşmo 
negro que não tem havido rompimento nesta occazião por thes faltar ainda hum ponto, assim como ouvio mais ao mesmo negro que para o projecto prezente era caixa o negro Diogo escravo de Joaquim dos Santos, o qual recebia de cada hum dos escravos convidados sem que muitos soubessem para o que certas quantias de dinheiro; pois a muitos se dizião que era para os - livrar de feitiços mostrando-lhes varios enchames, como bunecras e raizes declarando mais que alem do exposto que ouviu nạo só do referido negro mas tão bem do mesmo Miguel, e do Negro Cazemiro escravo da Maidelle testemunha, que a inssureição estava tramada de baixo de Comadantes, bem que o dito Cazemiro declarasse não saber para que haver na Fazenda do Bom Jardim o escravo Francisco com espingarda, na Fazenda das duas Pontes erão entrados o escravo Benedicto Ferreira, João congo tropeiro = epor capitão, Bento monjolo, e na Fazenda da Ponte alta, por Capitam Constantino monjolo, e entrados Elias, Antonio e Fabiano crioulo, e na Fazenda da Ponte alta de baixo por Capitam Joaquim congo, entrados Tristão, e Americo crioulo, Felezardo, Jacinto Benguella, e Malaquias Fazenda do Rio das pedras José Bexiga por capitam = Fazenda do Tacoaral João Monjolo por capitam = Fazenda do Monjolinho Jose duro por capitam = Fazenda de São Bento Jaruario Cabiuda por capitam, entrado Antonio Cabiuda, e na Fazenda do Sargento mor Andrade Irmão dele testemunha entrados Francisco cozinheiro, Francisco monjolo, e Jose congo = e na Fazenda da Mai delle testemunha Miguel Monjolo por capitam e na Fazenda de seu Irmão Teodoro Francisco de Andrade por comandante Miguel monjolo, designado Atibaia abaixo, e na Fazenda do - acima dito Joaquim Jose dos Santos por caixa o dito Diogo, e o Marcelino Monjolo, tropeiro que trazia as insinuações da Cidade, e na Fazenda do capitam Joze da Cunha Paes Leme, entrados Jose congo, e Manoelzinho, e na Fazenda de Salvador Bueno, entrados Bento cassuada, e Joaquim tropeiro, e na Fazenda de Antonio Correa Barboza entrados Agostinho monjolo, e Ignacio, persuadindo-se mais elle testemunha que o trama he manoblado pela maior parte dos escravos d'nasção monjolo, e congo, e mais não disse. E lido o seu depoimento pelo achar conforme assignou. Eu Manoel Francisco Monteiro Escrivam de Paz o escrevi $=$ Cunha $=$ Jose Franco de Andrade.

\section{TESTEMUNHA .}

Alferes Teodoro Francisco de Andrade homem branco, casado, natural da villa da Parnaiba de idade de quarenta annos, que 
vive de seu Engenho de Fabricar Assucar Testemunha jurada aos Santos Evangelhos em hum Livro delles, em que pôz sua mão direita, sobcargo do qual prometteo dizer o que scubesse.

Esendo the perguntado na Petição retro do Promotor do Juizo Joaquim Jose Soares de Carvalho, que toda lhe foi lida, e declarada.

Disse que a averiguação a que procedera seu Irmão o sargento Mór, Antonio Francisco d'Andrade, tendo elle testemunha levado o seu escravo de nome Miguel monjolo, ouvira a este dizer, que hum escravo de Joaquim dos Santos de nome Marcelino tropeiro tinha relações com o João Barbeiro rezidente na cidade de São Paulo, e que delle recebia insinuações para o motim que intentavão, e ouviu dizer mais ao mesmo escravo, que em caza do dito Santos havia outro escravo de nome Diogo dezignado caixa que recebia dinheiros de varios escravos com o fim de ser applicados para feitiços, ou couza de semelhantes enganos, e declarou que ouvira dizer ao mesmo escravo, que tinhão certa consulta entre elle, e hum de nome Miguel Monjolo, e outro de nome Francisco Monjolo, e que havia de ser em casa do escravo Bento Monjolo escravo do capitam mór Floriano, e que entam he que havia de saber o que te então elle ignorava, e que hé o que sabe elle testemunha, e que o mais saberá seu Irmão Major Andrade que he o que se habia incarregado destas averiguaçoens, emais rão disse.

$E$ lido o seu depimento, pelo achar conforme assignou com elle Juiz. Eu Manoel Francisco Monteiro Escrivam de Paz o escrevi $=$ Cunha $=$ Teodoro Francisco de Andrade $=$

\section{TESTEMUNHA .}

Manoel Jose do Amaral homem Pard osolteiro, natural da villa de Parnaiba de idade de quarenta annos morador desta, que vive de seu officio de carpinteiro Testemunha jurada aos Santos Evangelhos em hum Livro delles em que pos sua mão direita sobcargo do qual prometeu dizer a verdade que soubesse eperguntado pelo contheudo na petição detro do Promotor do Juizo Jose Soares de Carvalho que toda lhe foi lida e declarada.

Disse que achando-se trabalhando pelo seu officio de carpinteiro no sitio do Ajudante Jose Franco de Andrade ao tempo que Alferes Teodoro Francisco de Andrade ocupados na averiguação se achava ahi o mesmo Ajudante, o Sargento mor Andrade, e o da suspeita que havia dos escravos, ouvira epresenciara a hum dos escravos em confição dizer que da cidade de São Paulo dirigia o 
preto João Barbeiro pelo Marcelino escravo de Joaquim Jose dos Santos sobre que os escravos devião fazer, e que mais não sabe por que estava distrahido com as occupações de seu officio, e ais não disse.

Elido o seu depoimento, pelo achar conforme assignou com elle Juiz. Eu Manoel Francisco Monteiro Escrivão de Paz o escre$\mathrm{vi}=$ Cunha $=$ Manoel Jose do Amaral $=$

\section{CONCLUZAM.}

Elogo no mesmo dia mez e anno declarado no auto acima fez concluso o prezente Processo ao Senhor Juiz de $\bar{P}$ az Jose da Cunha Paes Leme, para despachar conforme seu merecimento. E para constar fiz este Termo de concluzão. Eu Manoel Francisco Monteiro Escrivam de Paz o escrevi. Conclusos.

\section{SENTENÇA .}

Procede o auto de corpo de delito, sejão recolhidos, ou retirados na cadeia os escravos indicados delinquentes que te agora se achavão prezos por diligencias de seus Patroens ou Senhores, aprocigão-se os termos do processo conforme ao requerido pelo Promotor, passando-se as mais ordens necessarias; segundo a urgencia da cauza. São Carlos treze de Fevereiro de mil oito centos trinta e dous. Joze da Cunha Paes Leme =-

\section{$D A T A$}

No mesmo dia, mez e anno, supra declardo, por elle Juiz de Paz Jose da Cunha Paes Leme me forão dađos estes autos com a sua Sentença retro que mandou se cumprisse e guardasse como nella se contem edeclara. E para constar fis este Termo de Data. Eu Manoel Francisco Monteiro Escrivam de Paz o escrevi.

\section{INTIMAÇAO .}

Certifico que intimei a sentença retro ao Promotor Joaquim Jose Soares de Carvalho e ao Curador João Maria de Couto em proprias pessoas. 
He verdade o referido, em fe do que passo a prezente. Sam Carlos quatorze de Fevereiro de mil oito centos trinta e dous o Escrivam de Paz Manoel Francisco Monteiro.

\section{TERMO DE JURAMENTO A PROMOTOR E CURADOR.}

Termo de juramento deferido a Joaquim Jose Soares, e ao Advogado João Maria de Couto, este para servir de curador por parte dos escravos entrados no trama da insurreição projectada pelos mesmos, e aquelle para servir de Promotor do Juizo, como abaixo se declara. Aos onze de Fevereiro de mil oito centos trinta e dous, nesta villa de Sam Carlos em casas do Juiz de Paz o capitam Jose da Cunha Paes Leme, e sendo ahi prezentes, e pessoalmente Joaquim Jose Soares de Carvalho, e o Advogado João Maria de Couto, que as reconheço, e dou fé. E por elle Juiz de Pas lhes foi deferido o juramento dos Santos Evangelhos em hum Livro delles, em que puzerão suas mãos direitas, sobcargo do qual thes encarregou que bem efielmente e izentos de paixão Servissem este de curador ad litem por parte dos escravos que vão ser interrogados em consequencia da Indicação que a este respeito digo Indicação que a este Juizo foi dada pelo Sargento mor Antonio Francisco de Andrade respeito ao projecto de inssurreição que tramavão os mesmos escravos, e a aquelle de Promotor deste Juizo para da mesma forma promover o quanto estiver ao seu alcance con as Leis e regras de Justiça. E recebido por elles ditos Promotor, e curador o dito juramento, assim o prometterão cumprir e observar, como lhes era encarregado. Do que para constar mandou elle Juis fazer este Termo que assignou com os mesmos depois de lido por mim Manoel Francisco Monteiro Escrivam de Paz o escrevi = Cunha. Joaquim Jose Soares de Carvalho $=$ João Maria de Couto $=$

\section{INTERROGATORIO DOS REUS. \\ TERMO DE PERGUNTAS AO PRETO JOSE CABINDA ESCRAVO DO SARGENTO MOR ANTONIO FRANCISCO DE ANDRADE.}

Aos onze de Fevereiro de mil oito centos trinta e dous nesta villa de São Carlos em casas do Juiz de Paz o Capitão José da Cunha Paes Leme, onde se achavão prezentes Joaquim Jose Soares de Carvalho como Promotor do Juiso, e o Advogado João Maria 
de Couto, como Curadr ad litem: esendo ahi prezente o preto Jose cabinda escravo do Sargento Mór Antonio Fraciscon de Andrade conduzido da cadeia desta villa em que se achava prezo para o effeito de ser interrogado. Eprocedendo elle Juiz no interrogatorio de que se trata.

Disse o Reo que o escravo Marcelino de Joaquim Jose dos Santos era que conduzia o dinheiro para a Cidade a entregar a João Barbeiro e que o escravo Diogo do mesmo Santos era o caixa que ajuntava o dinheiro dos outros, e que em diferentes Sitios tinha hum que se intitulava capitam, e era o caixa do dinheiro, e que Miguel monjolo, escravo do Alferes Teodoro Francisco de Andrade tambem procurava arrecadar varios dinheiros e que 0 escravo. Francisco de caza de seu Senhor de Nasção Moçambique, e Francisco monjolo parente de João Barbeiro da mesma casa e Francisco monjolo da caza e Miguel moniolo de caza de Donna Anna Mai do Sargento mor Andrade e Miguel monjolo do Alferes Teodoro Francisco de Andrade este mandou fazer ferragens que indicão offencivas na Ferraria do Capitam Mor Floriano do Engenho Atibaia e que os outros ja mencionados cada hum tinha a sua zagalha e que era para se levantarem, seduzidos por João Barbeiro, o qual prometia dara senha para conseguir seus intentos e que Miguel do Alferes Teodoro Francisco de Andrade hé que convidava a todos para os ajuntamentos de noite a tratarem desta materia incubrindo a maior parte delles a verdade do dia e destino certo de sua intenção bem como os escravos do capitão mor Floriano de nomes Bento monjolo, capitão, - Benedicto ferreiro e João congo tropeiro.

Os da Fazenda Ponte alta, do mesmo capitão mór Constantino monjolo capitão - Elias - Antonio Fabiano crioulo $=\mathrm{da} \mathrm{Fa-}$ zenda da Donna Anna de Campos - Joaquim congo capitam ristão - Americo crioulo - Felizardo - Jacinto crioulo digo Jacinto Benguela - Malaquias = da Fazenda do Rio das pedras do falescido coronel Francisco Ignacio - Jose Bixiga - capitam = da Fazenda do Monjolinho - Jose Duro Capitão $=\mathrm{Da}$ Fazenda de S. Bento do dito capitam mor Floriano Januario cabinda capitão - Antonio cabinda - Francisco, e Francisco monjolo Jose congo $=$ da Fazenda do capitam Jose da Cunha Paes Leme Jose congo e Manuelzinho $=$ da Fasenda de Salvador Bueno $=$ cassuada e Joaquim tropeiro $=$ da Fasenda de Antonio Correa Barboza Agostinho monjolo = e Ignacio, e mais não disse.

E desta forma ouve elle Juiz de Pas, Promotor, e Curador por feito, e concluido o prezente enterrogatorio, e para constar, man- 
dou faser este Termo que assignarão com as testemunhas a baixo depois de lido por mim Maroel Francisco Monteiro Escrivam de Pas o escrevi, e assigno $=$ Cunha $=$ Joaquim Jose Soares de Carvalho $=$ João Maria de Couto $=$ Antonio Januario Pinto Ferrás $=$ Domingos Jose de Andrade = Candido Moreira Machado = Manoel Francisco Monteiro =

\section{TERMO DE PERGUNTAS AO PRETO MIGUEL MONJOLO, ESCRAVO DO ALFERES TEODORO FRANCISCO DE ANDRADE.}

Aos quatorze de Fevereiro de mil oito centos trinta e dous, nesta villa de Sam Carlos em casas do Juiz de Paz Jose da Cunha Paes Leme, onde se achavão prezentes o Promotor do Juizo Joaquim Jose Soares de Carvalho e o Curador ad litem João Maria do Couto; esendo ahi tão bem prezente o preto Miguel Monjolo, escravo do Alferes Teodoro Francisco de Andrade para o effeito de ser interrogado sobre o projecto de inssurreição, tramado pelos escravos de varios Engenhos, segundo a Indicação que deo a este Juizo o Sargento mor Antonio Francisco de Andrade E procedendo elle Juiz ao mencionado interrogatorio.

Disse o Reo Miguel Monjolo, que indo elle ao Sitio de Joaquim dos Santos, e na casa do Moinho se achavão os escravos Diogo, e outro por alcunha Bexiga afilhado do mesmo Diogo, estes o chamarão, e tratando de o seduzirem por meio de enganos, com effeito o conseguirão, e ficou o Reo de cobrar dos Parceiros de sua caza algum dinheiro, e tão bem ficarem seduzidos para o mesmo effeito; e ajuntou elle Reo dez patacas dos parceiros, e as foi entregar ao Dicgo, e nessa occazião vio a caixa que tinha o Diogo, em que tinha bastante dinheiro, e que lhe dicera o dito Diogo, que não pençase que aquelle dinheiro era para elle Diogo, e que sim era para remetter a João Barbeiro, rezidente em São Paulo e que este hé que havia de applicar o dinheiro em beneficio delles todos, e que este Diogo era sedutor de todos escravos do Termo, de maons dadas com o João Barbeiro da Cidade de São Paulo. Disse mais que em sua casa se achava huma zagalha na mão de seu parceiro Jose, a qual foi dada por hum seu parceiro Francisco Monjolo, escravo do Sargento mór Antonio Francisco de Andrade, e que nos seus ajuntamentos nocturnos, e occultos dos brancos se aprezentavão alguns escravos do Bom Jardim armados co mespingardas, e que em todos os ajuntamentos, sempre o Diogo er ao cabeça, e mais não disse. E desta fórma houverão 
elles Juis, Promotor, e Curador por feito oprezente interrogatório. Epara constar fis este Termo que assignarão.

Eu Manoel Francisco Monteiro Escrivão de Pas o escrevi = Cunha $=$ Joaquim Jose Soares de Carvalho $=$ João Maria de Couto $=$

\section{PERGUNTAS AO PRETO DIOGO REBOLO, ESCRAVO DE JOAQUIM JOSE DOS SANTOS.}

Aos quatorze de Fevereiro de mil oito centos trinta e dous nesta villa de São Carlos em casas do Juiz de Paz José da Cunha Paes Leme, onde se achava o Promotor Joaquim Jose Soares de Carvalho e o Curador ad litem João Maria de Couto para o effeito de ser interrogado o preto Diogo Rebollo, escravo de Joaquim Jose dos Santos que prezente se achava.

Eprocedendo elle Juiz, e mais officiais supra dito no interrogatorio não foi possivel obter depoimento algum concorde a verdade: negou, e tounou a negar, nomeando diferentes nomes de negros na Cidade de São Paulo, e dando-lhes diferentes coragens, negando sempre que nunca conheceo a João Barbeiro, apezar dos escravos perguntados, achando se tão bem prezentes, the dizerem na cara, que elle era o que mandava em todos, e de todos recebia dinheiros, emandava para João Barbeiro, como fosse o Marcelino, que de huma vez levou dinheiro, e trouxe huma carta do dito João Barbeiro, e huma boceta de chifre: evendo elle dito Juiz, e mais officiaes, que o dito $\mathrm{Re}$ demonstrava todos os indicios de maldade, para incubrir a verdade, mandarão que fosse o mesmo ás grades da cadeia apanhar oa assoites da Lei, e tornado conduzido a presença do mesmo Juiz e officiais tornarão novamente a interrogar ao mesmo Reo o qual ainda posto em negaçõens imensas persuasoens que se the fez pouco a pouco se the foi descubrindo a verdade e declarou, que conhecia a João Barbeiro, com elle tinha correspondencia, e the fes remessa de dinheiros: vindo o dito Juiz, e officiais no conhecimento, tanto pelo dito dos mais escravos, como pela confição malicioza do Reo, que este mesmo era cabeça dos escravos entrados no projecto de inssurreição de mãos dadas com o dito João Barbeiro; tornarão a interrogar ao Reo Diogo, e logo descubrio, que tinha recebido a carta de João Barbeiro, mas negando sempre o que nella continha, e dizendo que a entregou a Pedrinho escravo do monjolinho, e majs não disse. Do que para constar mandou elle Juiz de Paz fazer este Termo de perguntas, que assignou com os officiais, Promotor, e Curador Joaquim Jose 
Soares de Carvalho, e João Maria de Couto depois de lido por mim Manoel Francisco Monteiro Escrivão de Pas o escrevi = Cunha $=$ Joaquim Jose Soares de Carvalho $=$ João Maria de Couto.

\section{PERGUNTAS A MARCELINO TROPEIRO.}

E logo no mesmo dia mez e anno, passando-se a interrogar ao preto Marcelino cabinda tropeiro escravo de Joaquim Jose dos Santos.

Disse o dito Marcelino, que nenhuma viagem que foi para São Paulo levou cinco patacas remetidas pelo Diogo, para entregar a João Barbeiro e este recebeo o dinheiro, e remeteo huma boceta e huma carta do mesmo Barbeiro para entregar aqui ao Diogo e que não sabia o que vinha na boceta, nem o que continha a carta, e que depois de lhe entregar, que hoverão dous mezes a esta parte, adoecera e té agora não andou mais na tropa; e que sabe que os escravos do Bom jardim, e do Alferes Teodoro Francisco de Andrade vinhão a casa de seu Senhor, e ahi fazião ajuntamentos secretos, os quaes lhe davão os cabeças hum titulo de Feitiços, ocultando o trama que permedittavão, amaior parte, que não julgavão com segredo, e que finalmente o cabeça era João Barbeiro na cidade, que nesta, o que figurava de caixa dos dinheiros e a quem todos obedecião era Diogo, que o Reo chama de Pai, emais não disse.

Epara constar fis este Termo, que assignão Juis, Promotor, e Curador depois de lido por mim Manoel Francisco Monteiro Escrivam de Paz o escrevi $=$ Cunha $=$ Joaquim Jose Soares de Carvalho $=$ João Maria de Couto.

\section{PERGUNTAS AO PRETO ANTONIO CABINDA.}

Elogo no mesmo dia, mez, e anno, passando elle Juis de Paz - Capitam Jose da Cunha Paes Leme, o Promotor Joaquim Jose Soares de Carvalho e o Curador ad litem João Maria de Couto, a interrogarem ao preto Antonio Cabinda escravo de Donna Blandina, filha do Capitam Mor Floriano.

Disse o Reo que he verdade que se juntou algumas vezes digo algumais noites com outros escravos Januario, e seu parceiro, e hião a Fazenda de Donna Anna de Campos, onde se juntavão tão 
bem escravos de outra parte occultamente sem que os brancos soubessem, e ali tratavão de varias conversas occultas, e elle Reo deo a Januario seu parceiro dinheiro, que de entre elles dous, andou em vinte esinco patacas, e dous Lenços, que tudo o dito Januario levou a entregar a Diogo escravo de Joaquim dos Santos, como cabeça de todos os escravos entrados nesta tentativa; emais näo disse. Epara constar fiz este Termo que assignão Juis, e officiais depois de lido por mim Manoel Francisco Monteiro Escrivam de Paz o escrevi $=$

\section{DECLARAÇÃO .}

Declaro que o Reo confessou o que fica dito, sem constrangimento de castigo, nem ferro, e sim mui volintariamente. Eu Manoel Francisco Monteiro o escrevi $=$ Cunha $=$ Joaquim Jose Soares de Carvalho $=$ João Maria de Couto $=$

\section{PERGUNTAS AO ESCRAVO JOAQUIM MESTRE FERREIRO DO CAPITAM JOAQUIM JOSE TEXEIRA NOGUEIRA.}

Aos quinze de Fevereiro de mil oito centos trinta edous, nesta villa de São Carlos, em casas do Juiz de Paz Jose da Cunha Leme estamdo prezentes o Promotor Joaquim Jose Soares de Carvalho, c o curador ad litem o Tenente João Maria de Couto, por elle Juiz ad junto com os ditos officiais procederão no interrogatorio, ao preto Joaquim Mestre ferreiro do capitão Joaquim Jose Texeira Nogueira, que para este fim foi conduzido de baixo de prizam.

Disse o Reo voluntariamente, sem força de castigo algum, ou villencia, que he verdade, que hia entrar em hua revolução contra os Brancos, para bem de sua liberdade, assacinando aos ditos Brancos, e que para isso foi convidado por hum mosso branco de nome Jose Valentim de Mello, o qual lhe dizia que esta intenção tão bem se achava tramada em São Paulo de comum acordo com os escravos desta, sendo que o dito mosso branco dizia para elle Reo, que depois de conseguirem os seus intentos, havião entre os que fossem entrados repartir o dinheiro, e mais cabedaes, que achassem, e que em virtude do convite deste mosso Mello, elle Reo convidasse ao preto Francisco, escravo de Suterio de tal, fazendo ver ao dito Francisco o mesmo que o dito Moço lhe fez ver, que os brancos estavão descuidados, e que já não havia mais ronda, emais não disse. Do que para constar mandou elle Juis de Paz fazer este Termo de perguntas que assignou com 
o Promotor Joaquim Jose Soares de Carvalho, e o Curador João Maria de Couto depois de lido por mim Manoel Francisco Monteiro Escrivam de Pas o escrevi = Cunha = Joaquim Jose Soares de Carvalho $=$ João Maria de Couto $=$

\section{TERMO DE PERGUNTAS AO PRETO FLAVIO BIXIGA ESCRAVO DE JOAQUIM JOSE DOS SANTOS.}

Aos dezaseis de Fevereiro de mil oito centos trinta edous, nesta villa de São Carlos, em casas do Juis de Pas Jose da Cunha Paes Leme ahi por elle epelo Promotor, e curador Joaquim Jose Soares, e João Maria de Couto, procederão ao interrogatorio do preto escravo de Joaquim Jose dos Santos de nome Flavio, por alcunha Bixiga, o qual sendo, perguntado pelo trama projectado entre os escravos.

Disse que hé verdade que fazião varios ajuntamentos de noite escondidos dos brancos, bem como elle recebia o dinheiro dos outros, e entregava ao Diogo escravo de Joaquim dos Santos e tanto assim elle dito Diogo tem comunicação com João Barbeiro, que Marcelino se achava disputando com o Diogo, para que elle havia de negar que tenha correspondencia com o dito João Barbeiro, quando os brancos já sabião de tudo, e que elle Reo recebeo do dito Diogo cinco patacas em recompença da guarda do dinheiro, e que o Marcelino tenha levado o dinheiro para a cidade a entregar a João Barbeiro, emais não disse. Do que para constar fiz este termo que assignão Juiz, e officiais depois de lido por mim Manoel Francisco Monteiro Escrivam de Paz o escrevi $=$ Cunha $=$ Joaquim Jose Soares de Carvalho $=$ João Maria de Couto $=$

\section{PERGUNTAS AO ESCRAVO JOSE DE NASÇÃo ESCRAVO DO FALESCIDO CORONEL FRANCISCO IGNACIO.}

Elogo no mesmo dia, procedendo-se a perguntas ao escravo Jose de Nasção do falescido Coronel Francisco Ignacio do Sitio Rio das pedras.

Disse que da insurreição tentada no anno passado, foi elle Reo em hum ajuntamento de muitos negros convidados por João Barbeiro, e influido para que se levantassem, e matassem aos brancos para ficarem libertos e que concorressem com dinheiro para elle João Barbeiro mandar fazer zagalhas, e comprar polvra, e 
que elle Reo não deo dinheiro algum, e nem quiz entrar, e que o dito João Barbeiro influia a todos para fazerem a guerra contra os brancos como na sua terra fazem huns com os outros, e da prezente insurreição intentada, nada sabe, senão por ouvir dizer, emais não disse. Epara constar fiz este Termo que assignão o Juiz, Promotor, e Curador ad litem depois de lido por mim Manoel Francisco Escrivam de Paz o escrevi = Cunha = Joaquim Jose Soares de Carvalho $=$ João Maria de Couto $=$

\section{PERGUNTAS A FRANCISCO, ESCRAVO DO MAJOR ANDRADE.}

No mesmo dia declarado retro, procedendo elle Juiz de Paz Jose da Cunha Paes Leme, ad junto com o Promotor Joaquim Jose Soares de Carvalho e o Curador ad litem João Maria de Couto no interrogatorio do escravo Francisco Mossambique escravo do Sargento Mór Antonio Francisco de Andrade.

Disse, que he verdade que o escravo Diogo de Joaquim dos Santos he o cabeça de todos os escravos, e qos quaes tem mandado arrecadar dinheiros por seu Afilhado Bexiga para remetter para São Paulo a Yoão Barbeiro com quem esta colloiado como outro igual cabeça, emais não disse. Eperguntado a outro escravo domesmo nome Francisco monjolo do dito. Sargento mór. Disse - mesmo do acima mencionado, e que não sabião overdadeiro fundamento, os quaes foram perguntados em liberdade, e sem constrangimerto de castigo. Epara constar fiz este Termo que assignaram depois de lido por mim Manoel Francisco Monteiro Escrivam de Paz o escrevi = Cunha $=$ Joaquim Jose Soares de Carvalho $=$ João Maria de Couto $=$

\section{PERGUNTAS AO PRETO FRANCISCO NAÇÃO CONGO, ESCRAVO DO BOM JARDIM.}

Aos dezasete de Fevereiro de mil oito centos trinta e dous, nesta villa de São Carlos, em casas do Juiz de Paz Jose da Cunha Paes Leme, por elle Juiz, Promotor, e Curador abaixo assignados Joaquim José Soares de Carvalho, e João Maria de Couto procedendo a perguntas ao preto Francisco de Nasção congo escravo do Bom Jardim.

Disse o Reo que denada sabia sobre a attentativa, e que apenas tinha comprado ao escravo Diogo de Joaquim dos Santos mei- 
zinhas de curar feitiços, por duas patacas, e nada mais dice. Epara constar fiz este Termo que assignaram Eu Manoel Francisco Monteiro Escrivam de Paz o escrevi = Cunha = Joaquim Jose Soares de Carvalho $=$ João Maria de Couto $=$

PERGUNTAS AOS PRETOS, ESCRAVOS DE DONNA ANNA DE CAMPOS PAES = AMERICO CRIOULO = FELIZARDO CRIOULO $=$ JOAQUIM CONGO = MALAQUIAS CONGO $=$ TRISTÃo CABINDA.

No primeiro dia digo No mesmo dia acima declarado entrando em perguntas o preto Americo crioulo.

Disse que na casa de sua Senhora o escravo Ezequiel por legitimo nome Joaquim de nação congo vendia meizinhas, assim como vendeo a elle Reo por cinco patacas, e quatro vintens, como comandante dos seus parceiros, cujas meizinhas erão para amançar brancos digo amançar aos brancos, e que fazião tais ajuntamentos de noite escondidos dos mesmos brancos, e este dinheiro era levado pelo dito Joaquim a entregar a Miguel, escravo do Alferes Teodoro Francisco de Andrade, e este, entregava ao cabeça de todos, Diogo escravo de Joaquim dos Santos, e este fazia remessa para a cidade de São Paulo cuja manobla oculta, elle Reo ignora. =

Sendo interrogado o dito Joaquim congo referido.

Disse que hé verdade que recebia alguns dinheiros dos parceiros e entregava a Miguel escravo do Alferes Teodoro Francisco de Andrade, e este entregava ao cabeça Diogo, escravo de Joaquim dos Santos, e este Diogo remetia para São Paulo. Disse mais que fazião varios ajuntamentos nocturnos, escondidos de seus Senhores, e que tão bem deo elle testemunha, digo deo elle Reo humas calças que custou quatro patacas e hum Lenço que custou hum cruzado, e assim mais que o dito Diogo enganava a maior parte delles dizendo em humas reizes que the dava que era para livrar de feitiços e que tinha hum Livro com a pintura do nariz de cachorro que era para adivinhaçõens. Sendo perguntado elizardo crioulo.

Disse o mesmo que os outros, respeito a raizes, e que deo trez patacas a Miguel para este entregar a Diogo escravo de Joaquim dos Santos e dizia este que remettia o dinheiro a hum seu Parente na cidade de São Paulo, e fazião ajuntamentos de noite oculto dos brancos, e disse mais que estas meizinhas era para amançar 
aos brancos para as armas dos mesmos não offenderem a elles pretos e se levantarem afoitamente com os mesmos brancos, mata-los, eficarem elles pretos todos forros, e que lhe dizia o Diogo que era precizo chegarem todos a huma dobla para ficarem bem crivados de chumbo, e armas dos brancos $=$

Reperguntando se ao Joaquim rongo pelo dito elizardo, disse ser verdade que com effeito as meizinhas se derigião a mançar aos brancos, e livrar a elles pretos do chumbo, e armas dos brancosdig o do chumbo, faca, e rondas da villa e a seu salvo matarem os brancos, è ficarem libertos.

Sendo interrogado o escravo Tristão cabinda. Disse que elle tãobem era entrado e que da sua parte deo dez patacas a Miguel, agente das cobranças, e este entregava o dinheiro seu, e dos outros ao Diogo dito e este remettia para São Paulo a outro cabeça, como era o Diogo, e que com effeito fazião ajuntamentos de noite ocultos dos brancos e que por este dinheiro hião recebendo meizinhas para casar aos brancos, e amançalos para náo offenderem a elles pretos com as suas armas e chumbo, e depois elles pretos se levantarem matarem aos brancos afoitamente, e ficarem libertos, cujo levante seria na ocazião de huma festa, e ajuntamento dos brancos.

Sendo interrogado o escravo Malaquias.

Disse que deo emprestada huma vestia a Miguel do Alferes Teodoro, e este não the deo mais, eprincipiou a induzilo para tomar meizinha e que mais nada sabe, cujos escravos forão perguntados e responderão voluntariamente independente de castigo, nem prizão. Do que para constar fis este Termo que assignam o Juiz e officiais. Eu Manoel Francisco Monteiro Escrivam de Pas o escrevi $=$ Cunha $=$ Joaquim Jose Soares de Carvalho $=$ João Maria de Couto $=$ Mandou elle Juiz declarar que Manoel de Campos Penteado visto que assistio atoda a interrogação e respostas dos escravos acima mencionados de sua Mai, e com administrador dos mesmos, que tâo bem assignasse, e assim tão bem a Antonio Januario Pinto Ferráz por ter a tudo prezenciado, e assentido. Eu Manoel Francisco Monteiro Escrivão que o escrevi $=$ Cunha $=$ Manoel de Campos Penteado $=$ Antonio Januario Pinto Ferráz = Joaquim Jose Soares de Carvalho = João Maria de Couto $=$ 


\section{PERGUNTAS AO PRETO FRANCISCO CRIOULO ESCRAVO DE SUTERIO ANTONIO.}

No mesmo dia declarado no Termo retro entrando em perguntas Francisco crioulo, escravo de Suterio Antonio.

Disse que no domingo, indo de recolhida para o Sitio encontrandose na sahida da villa, com Joaquim Ferreiro escravo do capitam Joaquim Texeira, entrando com elle em conversa, elle Reo dicera "ora Tio Joaquim, o Imperador, já convirão com elle do Reo, os negros já convirão com elle do Reo, os negros já não vem para o Brazil, não seria justo que nos dessem tão bem a liberdade? ao que the respondera o Joaquim, que alguma couza disso ha de acontecer. Enão se lembra de mais alguma outra conversa, que teria tal respeito, por que estava espiritualizado, de que reza quando vem a villa, emais não disse. Epara constar fiz este Termo que assignarão o Juiz, e officiaes, e testemunhas que prezentes se achavão. Eu Manoel Francisco Monteiro Escrivão de Pas o escrevi $=$ Cunha $=$ Joaquim Jose Soares de Carvalho $=$ João Maria de Couto $=$ Declaro que Suterio Antonio assigna com cruz $=$ Cruz de Suterio Antonio = estava a cruz $=$ Salvador Nunes de Brito $=$ Luciano Texeira Nogueira $=$ Antonio Januario Pinto Ferrás $=$

PERGUNTAS AOS ESCRAVOS DO CAPITAM MOR FLORIANO $=$ BENTO MONJOLO = BENEDICTO FERREIRO $=$ CONSTANTINO MONJOLO $=$ FABIANO CRIOULO $=$ ELIAS MOÇAMBIQUE $=$ ANTONIO CONGO.

Aos dezoito de Fevereiro demil oito centos trinta e dous nesta villa de São Carlos, em cazas do Juis de Paz Jose da Cunha Paes Leme, esendo ahi prezentes o Promotor de Juizo Joaquim Jose Soares dé Carvalho, e o Curador João Maria de Couto, por elle Juiz, e ditos officiais forão interrogados os escravos Antonio congo da Ponte alta.

Disse que algumas vezes tem assistido a ajuntamentos dos escravos de Donna Anna de Campos, e estes o induzirão para tomar meizinhas e darem dinheiro para levarem a Miguel do Alferes Teodoro, e este entregar a Diogo escravo de Joaquim dos Santos, cujo dinheiro ignora por nunca ter anuido, emais não disse $=$ dito. $=$

Fabiano crioulo da Ponte alta, disse o mesmo do acima 
Constantino monjolo Ponte alta disse que o escravo Miguel do Alferes Teodoro the vendeo meizinha por huma pataca, e que assistio ajuntamentos de noite oculto dos brancos em caza da Fazenda de Donna Anna de Campos, emais não disse.

Elias moçambique. Disse que os escravos de Donna Anna de Campos instavão para elle tomar meizinha, ao que elle não anuio, e que fazião seus ajuntamentos de noite oculto dos brancos e mais não disse.

Benedito ferreiro das Duas pontes, sendo interrogado.

Disse que elle assistia as funções de noite oculto dos brancos na Ponte alta de Donna Anna de Campos e que foi bastantemente convidado para tomar meizinha, e que não anuio, mas prezenciou em tais ajuntamentos, que a dita meizinha, era para animar, livrar de chumbo, e facas dos brancos, e o dinheiro hia de mão em mão te parar na mão do Diogo escravo de Joaquim Jose dos Santos, e que Miguel escravo do Alferes Teodoro levou a elle Reo hum molde para elle Reo fazer huma alaborda com farpa de engonço de sahir, e de entrar, o que elle não quis e mandou fazer po routros, mas por quem ignora emais não disse.

Bento monjolo das Duas pontes do Capitam Mor Floriano.

Disse que the consta desses ajuntamentos, mas que elle não era entrado, e que tudo o mais ignora.

Nesta occaziam sendo interrogado Jose Duro escravo da Fazenda do Monjolinho do Doutor Costa Carvalho.

Disse que de nada sabe; mas julgando se serem ás suas respostas com dolo, e malicia.

Januario cabinda escravo da Fazenda de São Bento do capitam Mór Floriano.

Disse que sabe dos ajuntamentos por ter assistido alguns, de noite e que foi tomar meizinha em casa de Diogo escravo de Joaquim dos Santos, e que esta era para o livrar de chumbo, e armas, emais não disse. Eçara constar fiz este Termo que assignarão. Eu Manoel Francisco Monteiro Escrivam de Paz o escrevi = Cunha $=$ Joaquim Jose Soares de Carvalho $=$ João Maria de Couto $=$ 


\section{TERMO DE REPERGUNTAS AO ESCRAVO FRANCISCO DE SUTERIO ANTONIO.}

Aos dezoito de Fevereiro de mil oito centos trinta e dous nesta villa de Sam Carlos, e casas do Juis de Pas Jose da Cunha Paes Leme e officiaes Promotor, e Curador procedendo na repergunta ao escravo Francisco, crioulo de Suterio Antonio ad junto com o Joaquim Mestre ferreiro do capitam Joaquim Texeira, e entrando em conferencias os dous, postos em liberdade.

Disse o Joaquim ao Francisco "Pois não te lembras eu dizer que na cidade se estava formando hum levante de escravos para se vir reunir com os daqui e formarem o levante, e que eu vos disse que Jose Valentim de Mello, filho do falescido Capitam Valentim de Mello fora o que me convidara e induzio anós todos, epor isso eu te convido; pois o dito mosso Jose Valentim promette, que matando se aos brancos, ficamos todos libertos, e se reparte o dinheiro?

Resposta - Respondeo Francisco, que com effeito se lembrava agora realmente ter sido assim tal, e qual emais não disse. Do que para constar fiz este Termo que assignou elle Juis, Promotor, e Curador, e testemunhas que prezentes se achavão depois de lido por mim Manoel Francisco Monteiro Escrivão de Paz o escrevi $=$ Cunha $=$ Joaquim Jose Soares de Carvalho $=$ João Maria de Couto $=$ Joaquim Jose da Silva $=$ Antonio Januario Pinto Ferrás $=$ Daniel da Silveira Cintra $=$ Salvador Nunes de Brito $=$ Cruz de Suterio Antonio = estava a cruz $=$ Cruz de Vicente Jose de Arruda $=$ estava a cruz $=$

\section{PERGUNTAS A MIGUEL MONJOLO ESCRAVO DE DONNA ANNA FRANCA CARDOZA.}

Aos vinte de Fevereiro de mil oito centos trinta e dous, nesta villa de São Carlos em casas do Juiz de Paz Jose da Cunha Paes Leme e sendo ahi prezentes o Promotor Joaquim Jose Soares de Carvalho, e o Curador João Maria de Couto, por elles Juiz, e officiaes procederão no interrogatorio ao escravo Miguel Monjolo de Donna Anna Franca Cardoza, o qual disse que recebia meizinha da mão de Miguel escravo de Teodoro Francisco de Andrade pela qual the deo duas patacas, a qual servia para o livrar de chumbo, e armas dos brancos, efazião seus ajuntamentos anoite, oculto dos brancos, emais não disse. Epara constar fiz este Termo que assignou elle Juis, e officiaes depois de lido por mim Manoel 
Francisco Monteiro Escrivão de Paz o escrevi = Cunha $=$ Joaquim Jose Soares de Carvalho $=$ Jose Maria de Couto $=$

\section{PERGUNTAS AO JOSE CONGO ESCRAVO DO CAPITAM JOSE DA CUNHA PAES LEME.}

Elogo no mesmo dia supra declarado, procedendo elle Juis e officiais ao interrogatorio a Jose congo escravo do capitão Jose da Cunha Paes Leme.

Disse que tomou meizinha de Miguel de Donna Anna Franca, e que era para não the calar ferro, nem chumbo. Epara constar fis este Termo que assignarão. Eu Manoel Francisco Monteiro Escrivão de Paz o escrevi $=$ Cunha $=$ Joaquim Jose Soares de Carvalho $=$ João Maria de Couto $=$

\section{PERGUNTAS AO ESCRAVO MANOEL CONGO DO CAPI- TAM JOSE DA CUNHA PAES LEME.}

Elogo no mesmo dia declarado no termo de perguntas a cima, procedeu elle Juis e officiais no interrogatorio do escravo Manoel Congo.

Disse que tomou meizinha do mesmo Miguel de Donna Anna Franca, ao qual deo huma pataca, emais não disse. Epara constar fiz este Termo que assignarão. Eu Manoel Francisco Monteriro Escrivão de $\mathrm{Paz}$ o escrevi $=$ Cunha $=$ Joaquim Jose Soares de Carvalho $=$ João Maria de Couto $=$

\section{BENTO CASSUADA ESCRAVO DE SALVADOR BUENO DA SILVEIRA.}

Procedendo a interrogatorio a Bento cassuada de Salvador Bueno da Silveira.

Disse que tomou meizinha de Francisco escravo do Sargento mor Andrade e que esta meizinha era para the livrar de chumbo, de faca, e de todas as mais armas de offença epara amançar a brancos, eque para isso trez lenços, huma carapuça, huma faca, e duas patacas em dinheiro, e fazião seus ajuntamentos nocturnos, escondido dos brancos, eque o dito escravo do Major Andrade dizia que este dinheiro hia parar na mão do Mestre, que hé escravo de Joaquim dos Santos, emais não disse. Epara constar mandou 
elle Juiz fazer este Termo que assignou com os officiai. Eu Manoel Francisco Monteiro Escrivam de Pas o escrevi = Cunha = Joaquim Jose Soares de Carvalho $=$ João Maria de Couto $=$

\section{PERGUNTAS AO ESCRAVO JOAQUIM MOSSAMBIQUE DE SALVADOR BUENO DA SILVEIRA.}

Interrogando se ao escravo Joaquim Mossambique de Salvador Bueno da Silveira.

Disse que algumas vezes acompanhou para o ajuntamento ao parceiro Bento cassuada; mas que não entrou, nem tomou meizinha, e que de nada sabe, emais não disse. Epara constar assignão Juis e officiais. Eu Manoel Francisco Monteiro Escrivão de Paz o escrevi $=$ Cunha $=$ Joaquim Jose Soares de Carvalho $=$ João Maria de Couto $=$

PERGUNTAS AOS PRETOS IGNACIO CABINDA, E AGOS. TINHO MONJOLO, ESCRAVOS DE ANTONIO CORREIA BARBOSA.

Eno mesmo dia procedendo se no interrogatorio dos escravos Ignacio cabinda, e Agostinho monjolo, ambos escravos de Antonio Correa Barboza dicerão.

Dicerão que de nada sabião. Epara constar fis este Termo, que assignarão Juis, e officiais. Eu Manoel Francisco Monteiro Escrivão de Pas o escrevi $=$ Cunha $=$ Joaquim Jose Soares de Carvalho $=$ João Maria de Couto $=$

\section{PERGUNTAS A JOÃO MONJOLO, DA FAZENDA DO} TACOARAL.

Aos Vinte, e hum de Fevereiro de mil oito centos trinta e dous, nesta Villa de São Carlos em casas do Juis de Pas Jose da Cunha Paes Leme, por elle, e mais officiaes abaixo assignados procederão nas perguntas ao escravo João Monjolo, o qual nada disse.

Epara constar fiz este Termo que assignação. Eu Manoel Francisco Monteiro Escrivão de Paz o escrevi = Cunha = Joaquim Jose Soares de Carvalho $=$ João Maria de Couto $=$ 


\section{PERGUNTAS AO ESCRAVO MARCELINO TROPEIRO DE JOAQUIM JOSE DOS SANTOS.}

Elogo no mesmo dia declarado no termo enfronte, procedendo se na repergunta ao escravo Marcelino Tropeiro de Joaquim dos Santos; Declarou mais, que na occazião que entregou as cinco patacas a João Barbeiro em São Paulo no Portão do Bexiga, o dito Barbeiro man dizer digo Barbeiro mandara dizer ao Diogo de Joaquim dos Santos que o dinheiro que lihe tinha mandado era pouco, e que tratasse de mandar maior remessa, e que no Rio de Janeiro os escravos já estavão libertos, e em São Paulo já se tinha dado baixa, aos vermelhos, e que se hiño assentar praça nos pretos, filho do falecido Pedrinho, que o esperasse sá em hum capão de Matos, entre o Santo Antonio e o Monjolinho, que elle pelo Natál, ou o mais tardar pela Quaresma, e que elle vinha a esta trazendo em sua companhia huma porção de escravos para se reunirem com os desta villa.

Do dito capão de mato onde pertendia fazer sua existencia, faria a participação as escravaturas dos Engenhos para se reunirem para guerrearem com os brancos, eficarem na sua liberdade, o que o dito Barbeiro pertendia viajar de noite da cidade a té o capão dito do Monjolinho.

Esendo chamado o dito João para ser interrogado, não foi possivel conseguir-se por andar fugido.

Do que para constar mandou elle Juis de Pas lavrar este Termo que assignou com os officiaes Promotor, e Curador depois de lido por mim Manoel Francisco Monteiro Escrivão de Pas o escrevi $=$ Cunha $=$ Joaquim Jose Soares de Carvalho $=$ João Maria de Couto $=$

TERMO DE PERGUNTAS AO ESCRAVO JOAQUIM CONGO DE FRANCISCO BORGES, EM CONSEQUENCIA DE HUMA PINTURA QUE SE ACHOU EM SUA MÃO.

Aos vinte e trez dias do mez de Fevereiro de mil oito centos trinta e dous annos, sendo pelo Juiz de Paz, e mais officiaes interrogado o escravo Joaquim congo de Francisco Borges da Costa como the tinha hido para ás maons huma pintura que se the aprezentou de hum negro coroado e hum branco, ponde lhe a coroa na cabeça, respondeo que Manoel de Nação Rebolo escravo 
do capitam Silverio Gurgel do Amaral Coitinho lhatinha vendido, esendo este chamado, respondeo que fez a pintura por ser de sua Arte para vender ao dito Joàquim, mas sen dolo, ou malicia, e mais não dicerão.

Do que para constar fiz este Termo eu Francisco Norato do Canto Escrivão interino do Juizo de Paz que no impedimento do actual o escrevi $=$ Cunha $=$ Joaquim Jose Soares de Carvalho $=$ João Maria de Couto $=$

\section{JUNTADA DE HUMA PETIÇÃO, INQUERIÇÃO DOS HOMENS LIVRES, E DE HUMA PINTURA.}

Aos vinte e trez dias do mes de fevereiro de mil oito centos trinta e dous annos, nesta villa de São Carlos em casas da rezidencia do Juis de Paz o capitam Jose da Cunha Paes Leme onde fui vindo eu Escrivão interino de seu cargo no impedimento do actual, e sendo ahi, junto a estes autos a pintura indicada no termo retro, bem como a Petição, e inquirição dos homens livres que tudo hé o que ao diante se segue. Do que para constar faço este Termo eu Francisco Morato do Canto Escrivão interino de Paz o escrevi $=$ Neste lugar se achava a mencionada Pintura $=$

\section{PETICAM.}

Illustrissimo Senhor Juiz de Paz Dig Joaquim Jose Soares de Carvalho na qualidade de Promotor deste Juizo, que procedendo de corpo de Delito indirecto formado sobre o projecto de inssureição entre a escravatura deste Termo, e em tal cazo devendo passar-se a inquiritorio testemunhal de pessoas livres, e lhe parece que ao mesmo tempo se deve continuar por inquiritorio, ou interrogatorio individual dos escravos, indicados delinquentes assim como vem remetidos de varias partes antes de se juntarrem na cadeia; visto que esta ainda não tem comodos de prisão em separada, e que assim formando se os distinctos Autos, ou termos de perguntas, em papel aparte, como já se praticou com o escravo, de nome Jose cabinda, podendo depois juntaria tudo ao processo em tempo oportuno. Portanto assim o reprezenta e Pede a Vossa Senhoria lhe defira como achar apropozito. E receberá merce $=$

\section{DESPACHO .}

$\mathrm{Na}$ forma reprezentada, assistindo o Curador, e junte-se a seu 
tempo, e em lugar competente. São Carlos treze de Fevereiro de mil oitocentos trinta e dous $=$

\section{ASSENTADA}

Aos quatorze de Fevereiro de mil oito centos trinta e dous nesta villa de São Carlos em casas do Juiz de Paz Jose da Cunha Paes Leme fui vindo eu Escrivão ao diante nomeado para o effeito de inquirir as testemunhas compreendidas de baixo desta Assentada, cujos nomes, sobre nomes, qualidades, naturalidades, estados, idades, e vidas ao diante vão, e se seguem. Do que para constar fiz este Termo de Assentada. Eú Manoel Francisco Monteiro Escrivam de Paz o escrevi =

\section{TESTEMUNHA.}

Manoel Rodrigues da Silva Homem branco solteiro natural de Santo Amaro de idade cincoenta e trez annos, morador desta villa que vive de sua lavoura, testemunha jurada aos Santos Evangelhos, em hum livro delles, em que pôs sua mão direita sob cargo do qual prometteo dizer averdade que soubesse e perguntado lhe fosse.

E sendo the perguntado pelo contheudo digo pelo que sabia a respeito d oprojecto de Inssurreição da Escravatura Disse que achando se elle Testemunha dentro em sua casa com a porta serrada no dia domingo doze do corrente percebeo que vindo dous negros, e sentando se em dous páos que se achão fora da dita caza, e entrando em conversa dizia hum ao outro "que ja havia oito centos mil reis, ou por outro nome dous mil cruzados, que hum elle tinha, e que os brancos se achavão descuidadoes e já não havia mais ronda, e que tudo se achava prompto para domingo sem falta, e que elle viesse bem armado sem segredo. enesta occazião conheceo elle testemunha, qu o que se dizia ao outro era de nome Joaquim já de idade, de capote, pardo, e que perguntando ao depois aos vizinhos quem era aquelle, dicerão que era o Mestre Joaquim Ferreira do Capitão Joaquim Teixeira, e o que pretendia seduzir, era Francisco, Negro de Suterio.

Disse mais elle testemunha que no dia quinta feira da semana passada, serião sete oras da noite percebeo na rua perto da sua casa o tropel de hum cavalo ferrado, e procurando saber quem seria conheceo que era hum negro e que chegando mais alguns, 
percebeo que $o$ dito cavaleiro the dizia que não podia demorar por que hia dar avizo a Fasenda do Monjolinho, e mais a outra, que elle testemunha não percebeo o nome dela, e que depois ainda havia de hir no Quilombo ou Colomba e que não sabia elle testemunha se era isto alguma Fazenda, ou Quilombo de Negros no mato, ou que elle testemunha percebeo que todo este negocio que tratavão era com muito empenho, mais não conheceo nenhum dos negros e que esta passagem o fes recear mais do que ouvira no domingo como já depoz, e mais não disse.

Elido o seu depoimento pelo achar conforme assignou com elle Juiz.

Eu Manoel Francisco Monteiro Escrivão de Paes o escrevi $=$ Cunha $=$ Manoel Rodrigues da Silva.

\section{TESTEMUNHA.}

Jose Leonardo Pereira, homem branco, solteiro, natural do Reino de Portugal, emorador desta villa de idade de concoenta e oito annos, que vive de Negocio de atacado, testemunha jurada aos Santos Evangelhos em hum livro deles, em que pos sua mão direita sobcargo do qual lhe incarregou elle Juis de Pas, dicesse averdade que soubesse eperguntado lhe fosse, pena de incorrer nas da Lei, recebido por elle o dito juramento assim oprometeo cumprir.

Esendo the perguntado o que sabia respeito ao projecto da inssurreição tramada pelos escravos deste Destricto.

Disse que ouvio dizer ao Sargento Mor Antonio Francisco de Andrade, que tinha descoberto nos seus escravos, de sua Mai, e dos Irmaons, e do Capitão Mor Floriano seguir o Club do anno passado do levante que tinhão formado, e que confeçando a huns dos seus, the tinha confeçado que João Barbeiro atiçava da cidade as Embaixadas a elles, pelos negros que hião com tropas da Cidade, e que tinha sustado com a prizão do dito Barbeiro, e que depois que elle sahio solto que entrou outra vez a avivalos, e que tivessem animo que ainda que padecessem alguma couza, que afinal os Brancos havião de pagar, e que tinha huma, sociedade que dava cada hum mensal certas quantias que elle testemunha não se lembra e que hum negro monjolo, ou congo de Joaquim Iose dos Santos era o caixa deste dinheiro, e que este dinheiro estava as ordens do dito João Barbeiro, e que breve esperavão a ordem delle para declararem atodos os negros, para que era o 
fim que fazião as suas cessoens de noite, que era pelo tal negro que andava pela cidade e que the declarava mais que pertendião ser forros matando aos Brancos, e que confessára ter trez zagalhas n'um porango, e que lhe forão dadas já da outra vez, e que esta courelação do tal João Barbeiro que era por todas as partes e mais não disse. Elido o seu depoimento pelo achar conforme assignou com elle Juis de Pas. Eu Manoel Francisco Monteiro de Paz o escrevi.

\section{CONTINUAÇÃO.}

Nesta occazião declarou mais elle testemunha, que lhe dissera João Ilhéo que o tal João Barbeiro Teve dous negros delle testemunha apoiados em sua caza que the andarão fugidos nove mezes e que de dia, the capinavão no quintal e de noite hião vender capim, e que elle Barbeiro mandara a esta villa estes negros pelo Natál, e depois tornarão-se asumir daqui e não sabe ao que vierão, e que os negros so contão que entravão em caza do dito Barbeiro, e conta o dito João Ilheo, que o capitão do Mato lhe contára no Bexiga que fora pegar hum, em caza do dito João Barbeiro, pelo outro que foi pagado primeiro o levar lá, e que la foi pegado o de nome constantino, emais não disse.

Elido seu depoimento assignou. Eu Manoel Fracisco Monteiro Escrivão de Paz o escrevi $=$ Cunha $=$ Jose Leonardo Pereira $=$

\section{TESTEMUNHA .}

João Jose da Cunha homem branco casado natural da Ilha Gracioza emorador nesta villa de idade de quarenta e oito annos, que vive de seu negocio, testemunha jurada aos Santos Evangelhos em hum livro delles em que poz sua mão direita, sobcargo do qual the encarregou ele $J$ uis dicesse averdade que soubesse $\mathrm{e}$ perguntado lhe fosse pena de encorrer nas da Lei, erecebido por elle testemunha o dito juramento, assim oprometeo cumprir. Esendo the perguntado pelo que sabia, respeito ao projecto de inssurreição tramada pelos escravos desta.

Disse que achando se elle testemunha na cidade de São Paulo no lugar chamado Bixiga na noite do dia quarta feira da semana passada a hi lhe contara hum capitaão do Mato, que naquelles dias havia pegado a dous escravos de Jose Leonardo Pereira e que pegando ao primeiro, este lhe o mostrára, que o outro estava na 
caza de João Barbeiro, onde trabalhava no quintal de dia, e que de noite hia vender capim, e que de facto elle capitão do mato achara o dito segundo escravo na caza de João Barbeiro a onde o pegara e que o dito capitão do mato, elle testemunha não conhece, e mais não dice.

Elido o seu depoimento pelo achar conforme assignou com cruz por mais não saber. Eu Manoel Francisco Monteiro Escrivão de Paz o escrevi $=$ Cunha $=$ Cruz de João Jose da Cunha $=$ estava a cruz $=$

\section{ASSENTADA .}

Aos dezaseis de Fevereiro de mil oito centos trinta e dous nesta villa de São Carlos, em cazas do Juiz de Paz Jose da Cunha Paes Leme fui vindo para o effeito de escrever os ditos dois testemunhas que sevão a inqquirir de baixo desta assentada a respeito do que sabem sobre oprojecto de inssurreição tramada por escravos deste Destricto cujas testemunhas seus nomes naturalidades, idades, qualidades, domicilios, e vidas ao diante vão, e seguem.

Do que para constar fiz este Termo de Assentada. Eu Manoel Francisco Monteiro Escrivão de Paz o escrevi.

\section{TESTEMUNHA}

Joze Manoel Abreu homem branco casado natural de Cuiabá de idade de secenta e trez annos mais, ou menos, que vive de seus negocios morador na. cidade de São Paulo eprezentemente nesta Villa, testemunha jurada aos Santos Evangelhos em hum livro delles em que poz sua mão direita sob cargo do qual the encarregou elle Juis dicesse averdade que subesse e perguntado lhe fosse; e recebido por ell o dito juramnto assim o prometeu cumprir.

Esendo the perguntado pelo que sabia arespeito do projecto de inssurreição tramado pelos escravos desta villa e seu termo.

Dice que indo a caza do Capitão Francisco de Paula Camarno no dia treze do corrente a tratar certo negocio, deste ouvira dizer, que na revolução dos negros que pertendião ao anno digo que pertendião aos negros fazer já elle dito capitão Paula teve denuncia de Jose Bento da Silva, e de Manoel Barbeiro hum pardo que foi do Conego Melchior, emais não disse. Elido o seu depoimento pelo achar conforme tinha deposto assignou com elle Juis de Paz. 
Eu Manoel Francisco Monteiro Escrivão de Paz o escrevi = Cunha $=$ Jose Manoel de Abreu Luz $=$

TESTEMUNHA.

Salvador Nunes de Brito homem branco solteiro natural de Cuibá emorador desta de idade aos Santos Envagelhos em hum livro delles em que pos sua mão direita sobcargo do qual the incarregou elle, Juis dicesse averdade que soubesse e perguntado lhe fosse, pena de incorrer nas da Lei; erecebido por elle o dito juramento, assim o prometeo cumprir.

Esendo the perguntado pelo projecto de inssurreição tramado pelos escravos desta villa e seu Termo. Disse que ouvira dizer, que Jose Bento tinha grande courelação, e amizade com os negros em que tratavão do prezente objecto de inssurreição, dizendo que fizessem o levante a bem da sua liberdade, visto que agora não devia haver escravidão, e que isto sabe por ouvir a Jose de Campos Soiza, e mais não disse. Elido o seu depoimento pelo achar conforme assignou. Eu Manoelle digo Manoel Francisco Monteiro Escrivão de Paz o escrevi $=$ Cunha $=$ Salvador Nunes de Brito $=$

\section{TESTEMUNHA.}

Manoel da Rocha Ribeiro homem branco casado natural da villa de Itú, emorador desta de idade de trinta annos, vive de seu negocio, testemunha jurada aos Santos Evangelhos em hum livro delles na forma da Lei. Esendo the perguntado o que sabia digo perguntado se sabia alguma couza sobre o projecto de inssurreição tramado pelos escravos desta.

Disse quem em sua casa aparecera huma pintura em papel, que continha estar hum negro sentado em huma cadeira, e dous brancos, hum de cada lado coroando ao negro e que esta pintura hum negro de Francisco Borges dera a huma criança delle testemunha, cuja pintura finalmente, levara o capitão Silverio Gurgel que a pedio par hir examinar se seria obra do seu escravo, visto que tinha hum escravo meio pintor, emas não disse. Elido seu juramento pelo achar conforme assignou. Eu Manoel . Francisco Monteiro Escrivão de Paz o escrevi $=$ Cunha $=$ Manoel da Rocha Ribeiro $=$ 


\section{ASSENTADA.}

Aos dezasete do mez de Fevereiro de mil oito centos trinta dous annos nesta villa de São Carlos e casas da rezidencia do Juiz de Paz Jose da Cunha Paes Leme onde eu Escrivam interino de Paz fui vindo no empedimento do actual para o effeito de inquirir e perguntar testemunhas, cujos nomes, cognomes, naturalidades, idades, officios, ditos, vidas, costumes são os que seguem . De que faço esta assentada. Eu Francisco Morato do Couto o escrevi $=$

\section{TESTEMUNHA.}

João Francisco Ferreira homem branco solteiro natural desta de idade de trinta e dous annos vive de sua lavoura, testimunha jurada aos Santos Evangelhos em hum livro delles, na forma da lei de baixo do qual prometteo dizer a verdade que soubesse $\mathrm{e}$ perguntado lhe fosse. Esendo lhe perguntado se sabia alguma couza respeito ao trama dos escravos.

Disse que indo para o Sitio de Luciano Texeira Nogueira hoverão treze dias mais ou menos alcançara ao preto Joaquim Ferreiro escravo do Capitam Joaquim Texeira, ahi lhe dicera o dito preto Joaquim que por cauza dos arreios delle testimunha, seu Senhor moço dito Luciano o havia castigado trez, mas que a quatro não havia chegar, e continuou adizer, que os brancos todos se achão libertos, e elles pretos por que não havião fịcar? isso era bello.

Eque estas couzas o dito preto repetira muitas veses, emais não disse. Elido seu depoimento pelo achar conforme assignou. Eu Manoel Francisco Monteiro Escrivam de Paz o escrevi = Cunha $=$ João Francisco Ferreira $=$

\section{TESTEMUNHA .}

Tenente Joaquim Jose da Silva homem branco solteiro natural da Cidade de Săo Paulo emorar desta villa de idade de trinta e seis annos, que vive de seu Engenho, testimunha jurada aos Santos Evangelhos em hum Livro delle na forma da Lei debaixo do qual prometeo dizer a verdade que soubesse eperguntado lhe fosse. Esendo the perguntado por elle Juis o que sabia arespeito do projecto de inssurreição de escravos. 
Disse que achando se aqui nesta casa cazulamente em occaziãoda conferencia do escravo Joaquim Mestre Ferreiro do Capitam Joaquim Texeira, com o preto Francisco crioulo de Suterio Antonio, ouvira, e prezenciara, a dita conferencia tal qual se acha escripto no Termo respectivo, onde assignou como testemunha emais não disse. Elido oseu depoimento pelo achar conforme assignou com elle Juis depois digo Juis. Eu Manoel Francisco Monteiro Escrivam de Paz o escrevi = Cunha = Joaquim Jose da Silva $=$

\section{TESTEMUNHA}

Antonio Januario Pinto Ferráz homem branco solteiro natural da cidade de São Paulo de idade de trinta, e hum annos, que vive de seu Engenho, testimunha jurada aos Santos Evangelhos em que pos sua mão direita sobcargo do qual the incarregou elle Juis dicesse averdade que soubesse eperguntado lhe fosse, e recebido por elle o dito juramento assim oprometeo cumprir. Esendo the perguntado pelo que sabia sobre oprojecto de inssurreição de escravos deste destricto.

Disse que achando se cazulamente prezente aqui nesta caza em occaziam da conferencia feita entre o escravo: Joaquim Mestre ferreiro do Capitão Joaquim Texeira com o escravo Francisco cioulo de Suterio Antonio, ouvira e presenciara a dita conferencia aqual he tal e qual se acha escripta no Termo respectivo, onde se assignou como Testimunha emais não disse. Elido seu depoimento pelo achar conforme assignou com elle Juis. Eu Manoel Francisco Monteiro Escrivam de Paz o escrevi = Cunha = Antonio Januario Pinto Ferraz =

\section{ASSENTADA}

Aos dezoito de Fevereiro de mil oito centos trinta e dous annos nesta vill a de São Carlos e casas de rezidencia do Juis de Paes Jose da Cunha Paes Leme onde eu Escrivam interino de seu cargo ao diante nomeado fui vindo para effeiro de inquirir e perguntar testimunhas cujos nomes, cognomes, naturalidades, idade, officios, ditos, vidas e costumes são os que ao diante se seguem. De que para constar faço esta assentada Eu Manoel digo Eu Francisco Morato do Couto Escrivão interino de Paz o escrevi $=$ 


\section{TESTEMUNHA .}

Salvador Nunes de Brito homem Branco Solteiro natural de Cuiabá de idade de trinta e sinco annos, que vive de seu negocio, emorador desta, villa, testimunha jurada aos santos Evangelhos em hum libro delles, em que pos sua mão direita sobcargo do qual prometeo dizer a verdade que soubesse eperguntado lhe fosse. Esendo lhe perguntado se sabia alguma couza, respeito ao projecto de levante dos escravos deste Destricto.

Desse que achando se casualmente aqui nesta caza de rezidencia delle Juis de Paz, em occazião da conferencia entre o escravo Joaquim Ferreiro do Capitão Joaquim Texeira, com o crioulo Francisco, escravo de Suterio Antonio, ouvira eprezenciara a dita conferencia a qual na verdade, hé tal, qual se acha escripto no termo respectivo, onde se assignou como testimunha, emais não disse. Elido seu depoimento pelo achar conforme assignou com o Juis. Eu Manoel Francisco Monteiro Escrivão de Paz o escrevi $=$ Salvador Nunes de Brito.

\section{TESTEMUNHA .}

Daniel da Silveira Cintra homem branco casado natural de São João de Atibaia de idade de quarenta esete annos que vive de ser feitor, Testimunha jurada aos Santos Evangelhos em hum livro delles em que pós sua mão direita sobcargo do qual prometteo dizer averdade que soubesse eperguntado the fosse.

Esendo lhe perguntado pelo projecto de inssureição de escravos. Disse que achando se cazualmente aqui prezente na occazião da conferencia do Ferreiro Joaquim escravo do capitam Joaquim Texeira com o crioulo Francisco escravo de Suterio Antonio, ouvira, e prezenciara a dita conferencia a qual na verdade hé tal qual se acha escripta no Termo respectivo, onde se assignara como testimunha, e mais não disse. Elido seu depoimento pelo achar conforme assignou com o Juiz de Paz. Eu Manoel Francisco Monteiro Escrivão de Pas o escrevi $=$ Cunha $=$ Daniel da Silveira Cintra $=$

\section{TESTEMUNHA .}

Vicente Jose de Arruda homem branco cazado natural de Bragança e morador desta de idade de vinte e oito annos, que 
vive de ser Feitor, Testimunha jurada aos Santos Evangelhos em hum livro delles em que pós sua mão direita sobcargo do qual prometeo dizer averdade que soubesse eperguntado lhe fosse. Esendo lhe perguntado se sabia alguma couza sobre o projecto de levante de escravos: Dice que achando se aqui nesta caza trazendo alguns escravos de sua Feitoz digo de sua Feitoria para serem interrogados, isto em tempo que conferenciação Joaquim Ferreiro, escravo do Capitam Joaquim Texeira, com o crioulo Francisco, escravo de Suterio Antonio, ouvira e prezenciara a mencionada conferencia, a qual he na verdade tal, qual se acha escripto no Termo respectivo, em que assignara como testimunha, emais não disse. Elido o seu Depoimento pelo achar conforme assignou com cruz por mais não saber. Eu Manoel Francisco Escrivão de Paes o escrevi $=$ Cunha $=$ Cruz de Vicente Jose de Arruda $^{-}=$Estava a cruz $=$

\section{TESTEMUNHA .}

Suterio Antonio homem branco cazado natural desta villa de idade, de trinta annos mais, ou menos que vive de lavoura Testimunha jurada aos Santos Evangelhos em hum livro delles, em que pós sua mão direita sobcargo do qual prometeo dizer a verse sabia alguma couza sobre o projecto de levante de scravos.

dade que soubesse eperguntado lhe fosse. Esendo the perguntado

Diss que achando se aqui nesta caza por ter vindo trazer o seu escravo Francisco Crioulo para ser reperguntado, a que ouvira, e prezenciara a conferencia que com 0 dito seu escravo fez o preto Joaquim Ferreiro escravo do Capitam Joaquim Texeira a qual conferencia hé tal, qual se acha escripto no termo respectivo onde se assignara como testimunha, emais não disse. Elido se depoimento pelo achar conforme assignou com cruz por mais não saber. Eu Manoel Francisco Monteiro Escrivam de Paz o escre$\mathrm{vi}=$ Cunha $=$ Cruz de Suterio Antonio $=$ estava a cruz $=$

\section{CONCLUZAM.}

De Concluzão $=$ aos vinte etrez dias domes de Fevereiro de mil oito centos trinta e dous annos nesta villa de São Carlos em cazas de rezidencia do Juiz de Paz Jose da Cunha Paes Leme onde eu Escrivão interino de seu cargo ao diante nomeado fui vindo no inpedimento do actual, e sendo a hi faço estes Autos conclusos para ser julgado conforme merecimento. Do que para 
constar faço este Termo. Eu Francisco Morato do Couto Escrivão interino no impedimento do actual o escrevi $=$ Concluzos $=$

\section{SENTENÇA.}

As testimunhas deste Summario obrigação aprizão, e livramento, em primeiro lugar a João Barbeiro como cabeça principal da inssurreição, duas vezes por elle premeditada, e aos escravos das seguintes Fazendas do Destricto desta villa - Bom Jardim = Francisco = Na Fazenda das Duas Ponte do Capitão mor Floriano - Bento Monjolo capitam $=$ Benedicto ferreiro $=$ João Congo tropeiro $=$ Fazenda da ponte alta pertencente ao mesmo Capitam = Constantino Monjolo capitão - Elias - Antonio Fabiano crioulo - Fazenda de Donna Anna de Campos = Joaquim congo capitam - Tristão - Americo - Felizardo - Jacinto Benguella - Malaquias - Fazenda do Rio da Pedras do falescido coronel Francisco Ignacio - Jose Bexiga capitam Fazenda do Taquaral - João Monjolo capitam - Fazenda do Monjolinho - Jose duro capitão - Fazenda de São Bento Januario cabinda capitam. Antonio cabinda - Fazenda do Sargento mor Antonio Francisco de Andrade - Francisco - Francisco Monjolo - Jose congo - Fazenda da Donna Viuva do falescido Capitam Mor Andrade - Miguel Monjolo capitam Fazenda de Joaquim Jose dos Santos - Diogo, que servia de caixa dos dinheiros, - eMarcelino tropeiro que servia de correio da correspondencia com o primeiro cabeça João Barbeiro - Fazenda do Capitam Jose da Cunha Paes Leme - Jose congo, e Manoelzinho - Fazenda de Salvador Bueno - Bento cassuada - Joaquim tropeiro - Fazenda de Antonio Correa Barbosa Agostinho monjolo, e Ignacio - O Escrivão lance seus nomes no Rol de culpados, epasse carta precatoria dirigida ás Justiças da Cidade de São Paulo para ser effectuada a prizão do primeiro cabeça João Barbeiro - e as ordens necessarias para serem prezos os mais Reos, que ainda não estiveram, remetendo-se logo todos com o prezente processo á Junta de Justiça da mesma Cidade, em cuja cadea ficarão em mais segurança.

Imperial Cidade de São Paulo, para a Villa de São Carlos onze de Mayo de mil oito centos trinta e dous. Jose da Cunha Paes Leme. Asseçor o Advogado Pinna $=$ Nada mais se continha em dito Processo de onde para, aqui bem efielmente fiz transcrever dos proprios autos, depois do que determinei ao Escrivão de meu cargo o que consta da data do teor seguinte. 


\section{DATA .}

Aos vinte e oito de Junho de mil oito centos trinta e dous annos nesta villa de São Carlos em casas do Juis digo em casas de morada do Juis de Paes Jose da Cunha Paes Leme, onde eu Escrivão de seu cargo ao diante nomeado fui vindo, esendo ahi por elle dito Juis me forão dados estes autos com sua sentença supra e retro, e mandou que se cumprisse, como nella se contem e declara, a saber que passe carta precatoria com o teor de todo - processo visto que no auto de corpo de delito não trata do Reo João Barbeiro e satisfeito assim, fizesse termo de remessa, dos originais para a Junta da Justiça ficando o traslado no cartorio deste Juizo para em consequencia delle se proceder nas de mais deligencia mencionadas em ditta Senttença.

Do Que para constar faço este termo. Eu Manoel Francisco Monteiro Escrivão de Paz o escrevi = Nada mais se continha em dito Termo de data, em virtude da qual sentença e mais processo fiz extrahir aprezente carta precatoria de diligencia ex officio, pelo teor da qual Reqqueiro a Vossas Senhorias dictos Meretissimos Senhores Juizes de Paz da Imperial Cidade de São Paulo a todos em geral e a cada hum em particular em seus respectivos Destrictos, freguezias, e lugares. Da Parte da Regencia em Nome do Imperador Dom Pedro Segundo da Naşão, e da minha muito de Merci lhes de preço, que indo esta por mim assignada a cumprão, guardem, efação muito inteiramente cumprir, e guardar comonella se contem e declara, em seu cumprimento, mandem por officiaes de Justiça de ante si, com os Auxilios, que necessarios forem prender a João de Naş̧̃̃o, e Mestre Barbeiro morador nessa cidade, e efeituada a diligencia, se recolha o mesmo as cadeias dessa cidade na forma da Setença aqui trancripta com toda a segurança, visto a sua criminalidade ser de tão grande consideração que pode cauzar a ruina da Nasção inteira, e satisfeita assim a deligencia façam remeter esta com a Certidão da deligencia, e captura, que muito espero em Vossas Senhorias, tomando em consideração hum caso tal, farão com que os officiais d' ante sifação huma Deligencia com á actividade precisa ao Doutor ouvidor da Comarca a quem vai neste momento remetido o Processo original, para como Relator da Justiça o aprezentar em Junta de Justiça, tudo ex officio de Justiça. Dada, epassada nesta villa de Sam Carlos aos onze dias domes de Agosto de mil oito centos e trinta e dous annos undecimo da Independencia e do Imperio. Eu Manoel Francisco Monteiro Escrivão de Páz a escrevi, e subscrevi. Jose da Cunha Paes Leme. V. F. I. Encza. Cunha. Cumpra-se S. Paulo de 16 de Agosto de 1832. Pinta. 
P. M. de prizão aos 17 de Agosto de 1832. Oliveira Matos. $\mathrm{Na}$ margem $-\mathrm{F}$. -8.350

As.il. 160

Sello nada

s. 8.350 Cunha

Certifico que em virtude do cumpra-se em frente, cumpri com o deliberado no mesmo; e acha-se prezo o:

R. declarado n'este Processo - Ex Officio

São Paulo 16 de Agosto de 1832.

Francisco Benedito de Oliveira Matos. 